\title{
ANALISIS TITIK IMPAS DAN BATAS AMAN SEBAGAI DASAR PERENCANAAN LABA JANGKA PENDEK PADA PT. SOHO INDUSTRI PHARMASI CABANG MANADO
}

\author{
Rachel Tangeren ${ }^{1}$, Jullie J. Sondakh ${ }^{2}$, Winston Pontoh ${ }^{3}$ \\ 1,2,3 Jurusan Akuntansi, Fakultas Ekonomi dan Bisnis, Universitas Sam Ratulangi, Jl.Kampus Bahu, Manado, \\ 95115, Indonesia \\ E-mail : rachelachsatangeren@gmail.com
}

\begin{abstract}
The main purpose of a company is to make a profit. Profits are not obtained automatically but it has to require a good planning. Tools that can be used by company management in planning earnings are breakeven analysis and margin of safety. Break even analysis studies company return point and margin of safety provides the information of the company sales before suffering a loss. The purpose of this study is to determine the breakeven point and margin of safety of PT. SOHO Industri Pharmasi Cabang Manado in the specific periodes so it can be used as a tool to plan for the future earnings. The analytical method used is qualitative with descriptive approach. The results of the study shows that in 20162017 the company is able to sells its product above the breakeven point which means they earned profits and the percentage of margin of safety is large which means the company is far from the point of loss.
\end{abstract}

Keywords: Breakeven Point, Margin of Safety, Profit Planning.

\section{PENDAHULUAN}

Di dalam menyusun perencanaan laba penjualan, manajemen membutuhkan informasi tentang pada tingkat penjualan berapa yang harus dicapai oleh perusahaan agar memperoleh laba atau pada tingkat penjualan berapa yang harus dicapai oleh perusahaan agar mencapai titik impas, atau pada tingkat penjualan berapakah perusahaan akan menderita kerugian. Dalam hal ini, salah satu alat bantu yang digunakan dalam manajemen adalah analisis titik impas, yaitu suatu analisa yang memberikan informasi tentang berapa tingkat penjualan yang harus dicapai agar perusahaan tidak menderita kerugian ataupun tidak mendapatkan keuntungan. Secara umum analisa ini juga memberikan informasi mengenai batas aman yang mempunyai kegunaan sebagai gambaran kepada manajemen berapakah penurunan penjualan dapat ditaksir sehingga usaha yang dijalankan tidak menderita rugi.

PT. SOHO Industri Pharmasi Cabang Manado adalah perusahaan yang bergerak di bidang farmasi. Perusahaan ini merupakan salah satu perusahaan yang mendistribusikan produk obat dari PT. SOHO Industri Pharmasi Global Health. Selain itu, PT. SOHO Industri Pharmasi Cabang Manado menjalin kerja sama dengan BPJS dalam penyaluran obat, sehingga mereka tidak mengambil untung atau laba pada obat tersebut. Produk yang memberikan laba terbesar dalam perusahaan adalah produk IMBOOST FORCE. PT. SOHO Industri Pharmasi Cabang Manado juga mendistribusikan produk PT. SOHO Industri Pharmasi Cabang Manado tidak hanya di daerah Sulawesi Utara namun di seluruh area Indonesia bagian timur.

Dalam penentuan laba volume penjualan, PT. SOHO Industri Pharmasi Cabang Manado belum menggunakan metode yang tepat, sehingga akan menimbulkan masalah untuk penjualan periode berikutnya. PT. SOHO Industri Pharmasi Cabang Manado belum melakukan pemisahan biaya-biaya kedalam biaya tetap dan variabel sehingga ada banyak pengeluaran biaya yang tidak sesuai. Dalam upaya perencanaan laba perusahaan, PT. SOHO 
Industri Pharmasi Cabang Manado perlu terlebih dahulu mengetahui titik pulang pokok dari penjualan pada periode sebelumnya (break even point) yaitu berapa banyak biaya atau pengorbanan yang telah dikeluarkan dan berapa banyak volume penjualan yang telah dihasilkan sehingga dapat diketahui titik impasnya, kemudian perlu menghitung batasan penurunan penjualan sehingga tidak terjadi kerugian (margin of safety), sehingga akan membantu manajemen dalam pengambilan keputusan dan melakukan perencanaan sehubungan dengan kebijakan untuk menaikkan laba. Maka dari itu perusahaan perlu melakukakan perencanaan laba perusahaan dengan menggunakan konsep Break Even Point dan Margin Of Safety.

\section{TINJAUAN PUSTAKA}

\subsection{Akuntansi Manajemen}

Menurut Rachmina dan Sari (2017:1), akuntansi manajemen merupakan proses identifikasi, pengukuran, pengumpulan, analisis, pencatatan, interpretasi dan pelaporan berbagai kejadian ekonomi dalam kegiatan usaha yang digunakan oleh manajemen dalam menjalankan fungsi manajemen (perencanaan, pengendalian dan pengambilan keputusan). Akuntansi manajemen adalah salah satu bidang ilmu akuntansi yang mempelajari bagaiman cara menghasilkan informasi keuangan untuk pihak manajemen yang selanjutnya akan digunakan untuk pengambilan keputusan. Umumnya informasi yang dihasilkan sifatnya lebih dalam dan biasanya tidak dipublikasikan. Hasil dari akuntansi manajemen berupa keputusan bidang keuangan (Sujarweni, 2016:2).

\subsection{Sistem Informasi Akuntansi Manajemen}

Menurut Hansen dan Mowen (2011:4), sistem informasi akuntansi manajemen (akuntansi biaya penuh, diferensial, dan pertanggungjawaban) memberikan informasi penting yang dibutuhkan perusahaan untuk memenuhi tujuan-tujuan manajemen. Akuntansi manajemen memiliki beberapa informasi yang dapat digunakan oleh perusahaan atau suatu badan usaha. Informasi akuntansi penuh adalah seluruh informasi tentang aktiva, pendapatan yang diperoleh, dan biaya baik masa lalu dan masa mendatang. Informasi akuntansi diferensial merupakan informasi yang dibuat untuk memilih salah satu alternatif pilihan pada perusahaan. Informasi akuntansi pertanggungjawaban merupakan informasi aktiva, pendapatan, biaya yang terjadi di pusat pertanggungjawaban yang ada dalam perusahaan (Sujarweni, 2016:6).

\subsection{Informasi Akuntansi Diferensial}

Menurut Salman dan Farid (2016:10), informasi akuntansi diferensial terdiri dari aktiva, pendapatan, dan atau biaya. Informasi akuntansi diferensial yang hanya bersangkutan dengan biaya disebut biaya diferensial (differential cost), dan yang hanya bersangkutan dengan pendapatan disebut pendapatan diferensial (differential revenues), sedangkan yang bersangkutan dengan aktiva disebut aktiva diferensial (differential assets). Terdapat 2 alternatif pengambilan keputusan yang terdapat dalam informasi akuntansi diferensial. Pertama adalah jangka pendek yang terdiri dari break even point, margin of safety, degree of operating leverage, shut down point, dan contribution margin. kedua adalah jangka panjang yaitu pemilihan keputusan investasi yang paling ekonomis yang terdiri dari investasi yang tidak menghasilkan laba, investasi yang tidak dapat diukur labanya, investasi dalam penggantian equipment, dan investasi dalam perluasan usaha.

\subsection{Perencanaan Laba Jangka Pendek}

Perencanaan laba jangka pendek merupakan aktivitas yang dilakukan oleh manajemen dalam proses penyusunanan anggaran perusahaan. Setiap manajemen dalam perusahaan selalu menemui kondisi dimana mereka mendapatkan pertanyaan "what if" dalam proses penyusunan anggaran atau apa yang akan terjadi jika manajemen memilih sesuatu. Maka dari itu dalam perencanaan laba jangka pendek, hubungan antara biaya, volume dan laba sangat 
berperan penting karena merupakan teknik yang tepat untuk menperhitungkan dampak perubahan harga jual, volume penjualan dan biaya terhadap laba demi membantu proses penyusunan anggaran oleh manajemen. Manajemen mempertimbangkan berbagai usulan kegiatan yang ada yang akan berakibat bagi perubahan harga jual, volume penjualan, maupun biaya variabel dan atau biaya tetap yang pada akhirnya akan memberi dampak pada laba bersih. Dampak terhadap laba bersih menjadi salah satu hal penting yang harus dipertimbangkan oleh manajemen dalam proses penyusunan anggran untuk pengambilan keputusan usulan kegiatan.

\subsection{Titik Impas (Break Even Point)}

Menurut Rachmina dan Sari (2017:142), analisis titik impas (break even point) adalah informasi yang digunakan oleh manajemen untuk mendapatkan gambaran tentang tingkat volume penjualan minimum yang harus dicapai agar perusahaan tidak mengalami kerugian ataupun untung. Titik impas sendiri dipengaruhi oleh pendapatan dan biaya. Apabila ada pilihan alternatif maka pilihan yang diambil ialah kegiatan yang memiliki titik impas kecil atau rendah. Dengan informasi titik impas, manajer suatu perusahaan dapat mengetahui tingkat penjualan yang diharapkan agar terhindar dari kerugian, dan kemudian dapat menentukan langkah-langkah yang tepat untuk periode yang akan datang. Dengan mengetahui titik impas penjualan, manajer dapat mengetahui tingkatan sasaran volume penjualan terendah yang harus dicapai oleh perusahaan yang dipegangnya. Break Even Point adalah kondisi yang menggambarkan bahwa total pendapatan adalah sama dengan total biaya, atau dengan kata lain laba perusahaan adalah nol. Break Even Point sangat berguna dalam menentukan perencanaan perusahaan (The dan Sugiono, 2015:94). Break Even Point atau titik impas adalah sebuah titik dimana jumlah pendapatan penjualan sama dengan jumlah biaya. Dengan demikian pada titik ini perusahaan tidak memperoleh laba, namun juga tidak menderita rugi (laba=0) (Krismiaji dan Aryani, 2011:170).

\subsection{Batas Aman (Margin of Safety)}

Margin keamanan adalah jumlah kelebihan dari penjualan yang dianggarkan (aktual) di atas titik impas volume penjualan. Margin keamanan menjelaskan seberapa besar jumlah pendapatan dapat menurun sebelum kerugian mulai terjadi (Rachmina dan Sari, 2017:142). Margin of safety merupakan elemen untuk mengukur tingkat keamanan penjualan perusahaan. Selain memberikan informasi seberapa jauh penurunan realisasi penjualan terhadap perencanaan penjualan sehingga perusahaan tidak rugi, margin keamanan akan digunakan manajer dalam menilai suatu risiko dari kegiatan operasi perusahaan yang dijalankan dan risiko rencana operasi yang akan datang.

\subsection{Perencanaan Laba}

Perencanaan laba merupakan rencana kerja perusahaan untuk mencapai target yang telah ditentukan. Perencanaan laba sering digunakan sebagai dasar dalam pengambilan keputusan investasi dan penilaian kinerja manajemen suatu perusahaan untuk masa yang akan datang (Baris \& Sondakh, 2014). Dengan menggunakan analisis titik impas dan batas aman, akuntan dapat menyediakan informasi yang berguna bagi manajemen untuk perencanaan laba. Akuntan dapat menentukan tingkat penjualan yang seharusnya dianggarkan untuk mencapai sejumlah laba tertentu. Aset perusahaan ditanam dalam sebuah proyek dengan tujuan untuk memperoleh laba. Laba yang diharapkan dari investasi tersebut disebut sebagai target laba (Sodikin, 2015:115). Perencanaan laba memiliki hubungan antara biaya, volume, dan harga jual. Biaya menentukan harga jual untuk mencapai tingkat laba yang dikehendaki, harga jual mempengaruhi volume penjualan, sedangkan volume penjualan mempengaruhi volume produksi (Munawir, 2011:184).

\subsection{Penelitian Terdahulu}

Beberapa penelitian terdahulu yang menjadi dasar pertimbangan penulis mengangkat penelitian ini adalah sebagai berikut. Pertama penelitian yang dilakukan oleh Sunanto pada 
tahun 2016 tentang Analisis Break Even Point dalam Menentukan Harga Sewa Kamar pada Hotel Ranggonan Sekayu, menyatakn bahwa pada tahun 2016 harga sewa kamar harus naik agar tidak rugi. BEP pada tahun 2013 telah mencapai titik impas, namun pada tahun 2014 dan 2015 belum mencapai titik impas karena pada tahun tersebut perusahaan mengalami kerugian. Pada penelitian yang dilakukan oleh Rismayani pada tahun 2014, tentang Peranan Analisis Break Even Point dalam Efektifitas Perencanaan Laba Jangka Pendek (Studi Kasus untuk Produk Plywood pada Pabrik Kayu CV. Restu Pertami) menyatakan bahwa peranan analisis BEP dalam efektifitas perencanaan laba jangka pendek menunjukkan adanya suatu peranan yakni dengan menggunakan analisis tersebut, CV. Restu Pertami dapat mengetahui dampak dari perubahan harga jual, biaya, dan volume penjualan terhadap laba.

\section{METODE PENELITIAN}

\subsection{Jenis Penelitian}

Jenis penelitian yang digunakan dalam penelitian ini adalah penelitian kualitatif dengan pendekatan deskriptif. Metode penelitian kualitatif adalah penelitian yang memiliki tujuan untuk memahami fenomena-fenomena mengenai subjek penelitian yang mengalami kejadian-kejadian contohnya adalah perilaku, persepsi, motivasi, tindakan, dll secara menyeluruh, dan dirangkum dengan cara deskripsi berbentuk kata-kata dan bahasa, pada suatu konteks khusus yang telah disediakan dan yang alamiah dan dengan memanfaatkan berbagai metode alamiah (Kuntjojo, 2009:14).

\subsection{Waktu dan Tempat Penelitian}

Tempat dilaksanakan penelitian ini adalah PT. SOHO Industri Pharmasi Cabang Manado yang bertempat di Jl. Pingkan Matindas, Tikala Baru, Paal Dua, Manado. Waktu penelitian dilaksanakan pada bulan Maret.

\subsection{Metode Analisis}

Metode analisis yang dilakukan melewati tahap-tahap sebagai berikut.

1. Menentukan Break Even Point (titik impas).

Menurut Salman dan Farid (2017:159), alat analisis yang dapat digunakan dalam mencari titik break even adalah sebagai berikut:

Atas dasar Rupiah:

$$
\operatorname{BEP}(\text { Rp. })=\frac{\text { Biaya Tetap }}{1-\frac{\text { Biaya Variabel }}{\text { Penjualan }}}
$$

Atas dasar unit:

$$
\mathrm{BEP}(\text { Unit })=\frac{\text { Biaya Tetap }}{\text { Harga per unit }- \text { Biaya variabel per unit }}
$$

2. Menentukan Margin of Safety (tingkat keamanan).

Rumus perhitungan margin of safety menurut Salman dan Farid (2017:162) adalah sebagai berikut:

Dinyatakan dalam unit:

Margin pengaman $=$ Total Penjualan - Penjualan pada Titik Impas

Dinyatakan dalam presentase:

$$
\text { Persentase margin pengaman }=\frac{\text { Margin pengaman dalam Rupiah }}{\text { Penjualan }} \times 100 \%
$$

3. Perencanaan laba yang direncanakan

Menurut Salman dan Farid (2017:161), ada dua metode untuk menghitung target laba yaitu: 
Jumlah penjualan (unit):

$$
\text { Jumlah Penjualan }=\frac{\text { Biaya Tetap }+ \text { Target Laba }}{\text { Harga per unit }- \text { Biaya variabel per unit }}
$$

Jumlah penjualan (Rupiah):

$$
\text { Jumlah Penjualan }=\frac{\text { Biaya Tetap }+ \text { Target Laba }}{1-\frac{\text { Biaya Variabel }}{\text { Penjualan }}}
$$

\section{HASIL ANALISIS DAN PEMBAHASAN}

4.1. Hasil Analisis

Data-data yang diperlukan mengambil data pada tahun 2016 dan 2017, yaitu:

Tabel 4.1

Hasil Penjualan dan Harga Jual Imbost Force Tahun 2016-2017

\begin{tabular}{|l|r|r|}
\hline & $\mathbf{2 0 1 6}$ & \multicolumn{2}{|c|}{$\mathbf{2 0 1 7}$} \\
\hline Harga jual per unit & 165.000 & 170.000 \\
\hline Jumlah unit terjual & 12.731 & 13.989 \\
\hline Total penjualan & Rp. 2.100 .615 .000 & Rp. 2.378 .130 .000 \\
\hline
\end{tabular}

Sumber: Data Olahan (2018)

Tabel 4.1 menunjukkan hasil penjualan tahun 2016 adalah 2.100.615.000 dengan jumlah unit terjual 12.731 dan harga jual per unit Rp. 165.000, dan tahun 2017 adalah 2.378.130.000 dengan jumlah unit terjual 13.989 dan harga jual per unit Rp. 170.000.

Tabel 4.2

Rincian Penggolongan Biaya Berdasarkan Perilaku Biaya

\begin{tabular}{|l|r|r|}
\hline \multicolumn{1}{|c|}{ Jenis Biaya } & 2016(Rp) & \multicolumn{1}{|c|}{$\mathbf{2 0 1 7}(\mathbf{R p )}$} \\
\hline Biaya tetap : & & 183.530 .000 \\
\hline Biaya gaji & 171.550 .000 & 95.000 .000 \\
\hline Biaya sewa & 95.000 .000 & 1.755 .454 \\
\hline Biaya fasilitas dan utilitas & 1.637 .212 & 280.285 .454 \\
\hline Total biaya tetap & 268.187 .212 & \\
\hline & & \\
\hline Biaya variabel : & & 40.513 .171 \\
\hline Komisi penjualan & 44.985 .990 & 77.768 .888 \\
\hline Biaya iklan dan promosi & 70.213 .908 & 350.154 .344 \\
\hline Biaya pengiriman & 370.008 .856 & 35.129 .648 \\
\hline Biaya admin & 37.754 .772 & 68.584 .421 \\
\hline Biaya fasilitas dan utilitas & 71.035 .179 & 14.512 .994 \\
\hline Biaya perlengkapan kantor & 12.739 .101 & 30.119 .726 \\
\hline Biaya lainnya (umum) & 28.973 .407 & 616.783 .192 \\
\hline Total biaya variabel & 635.711 .213 & 897.068 .646 \\
\hline Total biaya & 903.898 .425 & \\
\hline
\end{tabular}

Sumber: Data Olahan (2018)

Tabel 4.2 menunjukkan bahwa yang termasuk dalam biaya tetap adalah biaya gaji, biaya sewa dan biaya fasilitas dan umum. Kemudian yang termasuk dalam biaya variabel 
adalah komisi penjualan, biaya iklan dan promosi, biaya pengiriman, biaya admin, biaya fasilitas dan utilitas, biaya perlengkapan dan kantor dan biaya lainnya.

Tabel 4.3

Laba Bersih Penjualan Tahun 2016-2017

\begin{tabular}{|l|r|r|}
\hline & $\mathbf{2 0 1 6}$ & \multicolumn{1}{|c|}{$\mathbf{2 0 1 7}$} \\
\hline Penjualan & Rp. 2.100 .615 .000 & Rp. 2.378 .130 .000 \\
\hline Biaya variabel & Rp. 635.711 .213 & Rp. 616.783 .192 \\
\hline Biaya tetap & Rp. 268.187.212 & Rp. 280.285.454 \\
\hline Laba bersih & Rp. 1.196 .716 .575 & Rp. 1.481 .061 .354 \\
\hline
\end{tabular}

Sumber: Data Olahan (2018)

Tabel 4.3 menunjukkan laba bersih PT. SOHO Industri Pharmasi Cabang Manado tahun 2016 adalah sebesar Rp. 1.237.210.448 dan tahun 2017 sebesar Rp. 1.458.574.348.

\section{Analisis Titik Impas (Break Even Point)}

Perhitungan titik impas atas dasar rupiah (nilai uang) pada PT. SOHO Industri Pharmasi Cabang Manado adalah sebagai berikut:

Tabel 4.4

Break Even Point (Rp) 2016-2017

\begin{tabular}{|l|l|l|l|l|}
\hline & Biaya Tetap & Biaya Variabel & Penjualan & BEP(Rp) \\
\hline 2016 & Rp. 268.187 .212 & Rp. 635.711.213 & Rp. 2.100.615.000 & Rp. 383.124.588 \\
\hline 2017 & Rp. 280.285 .454 & Rp. 616.783.192 & Rp. 2.378.130.000 & Rp. 378.764.127 \\
\hline
\end{tabular}

Sumber: Data Olahan (2018)

Berdasarkan perhitungan di atas diketahui bahwa titik impas tahun 2016 pada PT. SOHO Industri Pharmasi Cabang Manado terjadi pada angka Rp. 383.124.588 dan 2017 pada RP. 378.764.127. Perhitungan titik impas atas dasar unit pada PT. SOHO Industri Pharmasi Cabang Manado adalah sebagai berikut:

Tabel 4.4

Break Even Point (Unit) 2016-2017

\begin{tabular}{|c|c|c|c|c|}
\hline & $\begin{array}{c}\text { Biaya } \\
\text { Tetap }\end{array}$ & $\begin{array}{c}\text { Biaya } \\
\text { Variabel/Unit }\end{array}$ & Harga/Unit & $\begin{array}{c}\text { BEP } \\
\text { (Unit) }\end{array}$ \\
\hline 2016 & Rp. 268.187.212 & Rp. 49.934 & Rp. 165.000 & 1.968 \\
\hline 2017 & Rp. 280.285 .454 & Rp. 44.090 & Rp.170.000 & 2.226 \\
\hline
\end{tabular}

Jadi, titik impas pada tahun 2016 adalah pada unit ke 1.969 dan pasa tahun 2017 adalah pada unit ke 2.226. Berdasarkan perhitungan titik impas dapat diketahui bahwa untuk mencapai titik impas sehingga perusahaan tidak akan mengalami kerugian maka dalam penjualan Imboost Force, PT. SOHO Industri Pharmasi pada tahun 2016 harus mampu menjual sama dengan Rp. 383.124.588 atau 1.969 unit dan pada tahun 2017 Rp. 378.764.127 atau 2.224 unit.

\section{Analisis Batas Aman (Margin of Safety)}

Perhitungan batas aman pada PT. SOHO Industri Pharmasi Cabang Manado adalah sebagai berikut:

$$
\text { Margin of Safety }=\text { Total penjualan }- \text { Penjualan pada titik BEP }
$$




\section{Tabel 4.4}

Margin of Safety 2016-2017

\begin{tabular}{|c|c|c|c|c|}
\hline & Penjualan & Penjualan BEP & MOS & \% \\
\hline 2016 & Rp. 2.100 .615 .000 & Rp. 383.124.588 & Rp. 1.717.490.412 & 81,8 \\
\hline 2017 & Rp. 2.378.130.000 & Rp. 378.764.127 & Rp. 1.999.365.873 & 84 \\
\hline
\end{tabular}

Sumber: Data Olahan (2018)

Berdasarkan perhitungan yang telah disajikan, presentase batas aman PT. SOHO Industri Pharmasi pada tahun 2016 adalah sebesar Rp. 1.717.490.412 atau 81,8\% dan pada tahun 2017 adalah sebesar Rp. 1.999.365.873 atau 84\%.

\section{Analisis Perencanaan Laba}

Apabila perusahaan ingin menentukan berapa laba yang diinginkan atau direncanakan untuk tahun berikutnya dapat menggunakan rumus sebagai berikut:

$$
\text { Jumlah Penjualan }=\frac{\text { Biaya Tetap }+ \text { Target Laba }}{1-\frac{\text { Biaya Variabel }}{\text { Penjualan }}}
$$

Dengan menggunakan rumus tersebut maka perusahaan dapat dengan mudah menghitung perencanaan laba. Misalkan apabila perusahaan untuk memperoleh laba pada tahun berikutnya sebesar Rp. 1.500.000.000 maka besarnya penjualan yang harus dicapai untuk mencapai target laba tersebut adalah sebagai berikut:

$$
\begin{aligned}
\text { Penjualan (Rp.) } & =\frac{280.285 .454+1.500 .000 .000}{1-\frac{616.783 .192}{2.378 .130 .000}} \\
& =\frac{1.780 .285 .454}{1-0.26} \\
& =2.405 .791 .154
\end{aligned}
$$

Berdasarkan perhitungan yang telah diselesaikan di atas, agar dapat memperoleh laba sebesar Rp. 1.500.000.000 maka PT. SOHO Industri Pharmasi harus dapat menjual produknya sebesar Rp. 2.405.791.154 untuk tahun berikutnya.

\subsection{Pembahasan}

Hasil pengujian menunjukkan bahwa agar tidak mengalami kerugian perusahaan harus melakukan penjualan di atas titik impas yaitu pada Rp. 383.124.588 atau 1.969 unit dan pada tahun 2017 Rp. 378.764 .127 atau 2.224 unit. Kemudian berdasarkan perhitungan yang telah disajikan, perhitungan margin of safety ini memberikan informasi berapa maksimum volume penjualan boleh turun agar perusahaan tidak menderita rugi. Maka presentase batas aman PT. SOHO Industri Pharmasi pada tahun 2016 adalah sebesar Rp. 1.717.490.412 atau 81,8\% dan pada tahun 2017 adalah sebesar Rp. 1.999.365.873 atau 84\%. Dengan metode batas aman ini berguna untuk perusahaan agar dapat menjaga penjualan untuk tidak melampui rasio batas aman tersebut. Presentase ini menunjukkan bahwa perusahaan memiliki kesempatan untuk memperoleh laba yang besar karena perusahaan memiliki presentase batas aman yang cukup besar untuk dua tahun terakhir. Untuk perencanaan laba jika perusahaan ingin memperoleh laba sebesar Rp. 1.500.000.000 maka PT. SOHO Industri Pharmasi harus dapat menjual produknya sebesar Rp. 2.405.791.154 untuk tahun berikutnya. Hasil secara keseluruhan menunjukkan bahwa pada tahun 2016 dan 2017 keadaan perusahaan ada dalam 
keadaan yang baik karena telah berhasil menjual produknya di atas titik impas dan jauh dari batas aman sehingga jauh dari kemungkinan terjadinya kerugian.

\section{KESIMPULAN DAN SARAN}

\subsection{Kesimpulan}

Berdasarkan hasil penelitian dan pembahasan pada bab sebelumnya, maka disimpulkan bahwa:

1. Secara umum, kinerja penjualan dan pengelolaan biaya-biaya yang dilakukan oleh PT. SOHO Industri Pharmasi Cabang Manado sudah baik, namum perusahaan belum mengklasifikasikan biaya-biaya tersebut ke dalam biaya variabel dan biaya tetap.

2. Penjualan yang dilakukan oleh PT. SOHO Industri Pharmasi Cabang Manado sudah sangat baik karena pada tahun 2016 dan 2017 sudah dapat menjual produknya jauh di atas titik impas.

3. Pada tahun 2016 dan 2017 batas aman PT. SOHO Industri Pharmasi Cabang Manado cukup tinggi yang berarti bahwa perusahaan berada dalam keaadan yang baik, karena untuk kedepannya kemungkinan untuk menderita kerugian tergolong rendah jika perusahaan dapat mempertahankan kinerja serta titik impas dan batas aman seperti ini.

\subsection{Saran}

1. PT. SOHO Industri Pharmasi Cabang Manado sebaiknya dapat menerapkan analisis titik impas dan batas aman sebagai alat bantu perencanaan laba agar bisa mendapatkan informasi mengenai penjualan yang harus dicapai agar target laba tercapai dan informasi mengenai tingkat penurunan penjualan sebelum mengalami kerugian.

2. Batas aman perusahaan untuk tahun 2016 dan 2017 sudah cukup baik, namun perusahaan harus dapat selalu mempertahankan penjualan di atas batas aman tersebut agar perusahaan tidak menderita kerugian dan dapat memperoleh laba yang lebih besar.

3. Untuk dapat menggunakan analisis titik impas dan batas aman, perusahaan perlu untuk memisahkan biaya-biaya operasional yang ada ke dalam biaya tetap dan biaya variabel.

\section{DAFTAR PUSTAKA}

Baris, Y.E, dan Sondakh, J.J. 2014. Analisis Break Even Point Sebagai Alat Perencanaan Laba Produk Gorengan Pada Usaha Kecil Menengah (UKM) Di Kawasan Boulevard Manado. Jurnal EMBA 2(3): 1678.

Hansen dan Mowen. 2011. Managerial Accounting (Akuntansi Manajerial). Buku 2. Edisi 8. Salemba Empat. Jakarta.

Hernanto. 2017. Akuntansi Biaya - Sistem Biaya Historis. ANDI dan BPFE. Yogyakarta.

Krismiaji dan Aryani, Y Anni. 2011. Akuntansi Manajemen. Edisi Kedua. Sekolah Tinggi Ilmu Manajemen YPKN. Yogyakarta.

Kuntjojo. 2009. Metodologi Penelitian. Universitas Nusantara PGRI Kediri. Kediri.

Lestari, W. dan Permana, D. B. 2017. Akuntansi Biaya dalam PerspektifManajerial. Rajawali Pers. Depok.

Machfoedz, Mahmud. 2007. Pengantar Bisnis Modern. ANDI. Yogyakarta.

Munawir. 2011. Analisis Laporan Keuangan. Liberty. Yogyakarta.

Rachmina, D. dan Sari, S.W. 2017. Akuntansi Manajemen Teori dan Aplikasi. Cetakan Keempat. Polimedia Publishing. Jakarta.

Salman, K.R, dan Farid, EC. M. 2017. Akuntansi Manajemen Alat Pengukur dan Pengambilan Keputusan Manajerial. Indeks. Jakarta.

Sodikin, S.S. 2015. Akuntansi Managemen Sebuah Pengantar. Edisi Kelima. UPP STIM YPKN. Yogyakarta.

The, I. dan Sugiono, A. 2015. Akuntansi Informasi dalam Pengambilan Keputusan. PT Grasindo. Jakarta. 